\title{
B-Cell Differentiation
}

National Cancer Institute

\section{Source}

National Cancer Institute. B-Cell Differentiation. NCI Thesaurus. Code C28391.

In mammalian bone marrow, B-Cell Development consists of progressive differentiation from CD34+ progenitor cells to plasma and memory B cells by positive/negative selection in response to local signals, including antigens and cytokines. B cell development begins with immunoglobulin gene somatic recombination and pre-B cell receptor expression. Antigen-induced signal transduction via BCR-associated ITAM molecules activates B cell proliferation. Further differentiation involves additional immunog lobulin gene recombination and expression. Antigen-stimulated circulating (resting) B cells proliferate and differentiate into plasma and memory B cell clones expressing immunog lobulins with the same antigen recognition site. 